\title{
Insider Trading in Germany - Do Corporate Insiders Exploit Inside Information?
}

Björm M.Dymke, Department of Banking, University of Tübingen, Germany, E-Mail: bjoern.dymke@uni-tuebingen.de Andreas Walter, Department of Banking, University of Tübingen, Germany,E-Mail: andreas,walter@uni-tuebingen.de

\begin{abstract}
Our study focuses on the question whether corporate insiders in Germany exploit inside information while trading in their company's stock. In contrast to prior international studies, which are not able to link insider transactions to a formal definition of inside information, we relate insider transactions to subsequent releases of inside information via ad-hoc news disclosures. We find evidence that corporate insiders as a group seem to trade on inside information. Moreover, members of the supervisory board seem to be most active in exploiting inside information, since they realize exceptionally high profits with their frequent front-running transactions.
\end{abstract}

Keywords: insider trading, inside information, $\S 15 a$ WpHG, German stock market, regulation of financial markets

Manuscript received July 13, 2007, accepted by Christian Schlag (Finance) May 6, 2008.

\section{Introduction}

The question whether corporate insiders exploit inside information while trading in their company's stock attracts the attention of academia and the public alike. ${ }^{1}$ Moreover, the answer to this question is also crucial for regulatory authorities, since on a capital market there is a loser for each winner. In particular, if corporate insiders exploit inside information, profits received by corporate insiders reduce the returns of all other uniformed traders (including the market maker). ${ }^{2}$ As a consequence, un-

\footnotetext{
${ }^{1}$ In 2005, according to its annual report, the German regulatory authority Bundesanstalt für Finanzdienstleistungsaufsicht (BaFin) investigated 54 cases related to suspected insider trading. E.g., several managers at DaimlerChrysler were suspected to exploit inside information prior to the resignation of the former CEO Jürgen Schrempp (Handelsblatt, August 29, 2005). However, the probably most prominent suspicion was about the former Co-CEO of the European Aeronautic Defence and Space Company (EADS), Noël Forgeard, who sold together with his children stocks and stock options for a seven digit profit just a few weeks before EADS disclosed severe difficulties in the production of the airplane A380 (IIandelsblatt, June 21, 2006).

2 Admittedly, this discussion highlights the disadvantages of insider trading exclusively and thus gives an incomplete picture. The reader should be aware that there exists a large body of
}

informed investors might refrain from trading on the capital market. Thus, a well developed capital market requires an effective insider regulation to protect uninformed investors. In order to analyze the effectiveness of insider trading regulations in Germany, our study basically addresses three questions. First, we analyze whether German corporate insiders earn abnormal profits while trading in their company's stock. Second, we use a distinct property of German law, i.e., the companies' obligation to reveal inside information through ad-hoc news disclosures, to examine whether profits realized by corporate insiders seem to be due to the exploitation of inside information or not. Finally, we explore which group of insiders seems to be most active in trading on inside information: the one which is best informed about a company's prospects (i.e., senior managers) or the one which is probably least closely watched by the regulator (i.e., family members of senior managers and directors). Today, insider

literature which emphasizes the beneficial role of insider trading. E.g., Manove (1989) and Leland (1992) favor the permission of insider trading to increase informational efficiency of security prices. 
regulations prohibit the exploitation of inside information on capital markets in nearly all developed countries. ${ }^{3}$ In Germany, since 1994 § 14 WpHG (Security Trading Act) prohibits the exploitation and transmission of inside information. According to German law, inside information can be described as any specific information which is not subject to public knowledge and which, if it became publicly known, would likely have a significant effect on the stock price of the respective company ( $\$ 13 \mathrm{WpHG}$ ). Moreover, to enhance market efficiency and to avoid information asymmetry § $15 \mathrm{WpHG}$ requires an immediate public disclosure (ad-hoc announcement) of any inside information (as defined in $\S 13$ $\mathrm{WpHG}$ ) by the respective company. Additionally, as corporate insiders (i.e., senior managers, directors and their family members) may possess superior information about the company, since July 1, 2002 $\S 15 \mathrm{a}$ WpHG requires companies to report corporate insiders' transactions to the public as well as to the regulatory authority, the Bundesanstalt für $\mathrm{Fi}$ nanzdienstleistungsaufsicht (BaFin) ${ }^{4}$

Trading activities of corporate insiders have been subject to a large number of studies. One strand of literature focuses on the announcement day of insider transactions and explores if uninformed outsiders can benefit by mimicking insider transactions (e.g.,

1988; Bettis, Vickrey and Vickrey 1997; and Fidrmuc, Goergen, and Renneboog 2006). Remarkably, the literature finds that even uninformed outsiders can earn abnormal profits using publicly available information, at least when transaction costs are ignored.

Another strand of literature is motivated by the question whether corporate insiders earn abnormal profits by trading in company's stock and thus may use their foreknowledge about their firms' prospects (e.g., Lorie and Niederhoffer 1968; Jaffe 1974; Finnerty 1976; Seyhun 1986; Eckbo and Smith 1998; Jeng, Metrick, and Zeckhauser 2003; Lakonishok and Lee 2001). The international literature documents that insiders earn high abnormal profits while trading in company's stocks. ${ }^{5}$ While there

3 Bhattacharya and Daouk (2002) show that insider trading laws existed in 87 out of 103 countries with a capital market.

4 Section 2 of this paper discusses the definition of corporate insiders as well as the regulation and reporting requirements for insider trades in more detail.

5 A differing result is reported by Eckbo and Smith (1998). exist numerous studies focusing on insider trading in the US and the UK, until now not much research has been conducted on the German capital market. This may be due to the fact that until July 1, 2002 corporate insiders did not have to reveal their trades to the regulatory authority. ${ }^{6}$ However, recent studies for Germany (see, e.g., Stotz 2006; Klinge, Seifert, and Stehle 2005; Betzer and Theissen 2005) confirm the finding that corporate insiders earn significant profits. In particular, Stotz (2006) examined insider profits as well as the market reaction at the announcement day documenting positive abnormal returns for insiders as well as for outsiders in the first year following the implementation of the reporting obligation in Germany. In addition, he shows that German corporate insiders act as contrarian investors. Klinge, Seifert, and Stehle (2005) also analyze the market reaction around the announcement and trading day focusing mainly on determinants of the market reaction at the announcement day. Furthermore, they focus on the relevance of analyzing non-overlapping observations. Betzer and Theissen (2005), amongst other issues, relate the magnitude of market reaction to the ownership structure of the firm and thus contribute to the corporate governance literature. Finally, Betzer and Theissen (2007) find that prices are distorted in the period between the trading and the reporting date and thus propose a regulation which requires an immediate disclosure of insider transactions.

Although most prior studies routinely attribute abnormal profits to insider's superior knowledge and therefore to a potential exploitation of inside information, a final assessment is anything but trivial. On the one hand, profits of insiders could indeed originate in the exploitation of inside information. On the other hand, short-term profits documented for corporate insiders could at least partly triggered by price-pressure caused by outsiders who blindly mimic the trades of insiders in a herd-like manner, even though the insiders traded just for liquidity considerations and not on inside information. Therefore, recent studies have tried to link trading activities of insiders to their foreknowledge of important corporate events, including bankruptcy (Seyhun and Bradley 1997), dividend initiations

\footnotetext{
6 Until July 1, 2002 only companies listed on the Neuer Markt segment were required to report insider trading records to the Deutsche Börse AG.
} 
(John and Lang 1991), seasoned equity offerings (Karpoff and Lee 1991), stock repurchases (Lee, Mikkelson, and Partch 1992), takeover bids (Seyhun 1990), and earnings announcements (Elliott, Morse, and Richardson 1984; Noe 1999; and Ke, Huddart, and Petroni 2003). These studies basically find that insiders trade upon forthcoming corporate news. Thus, the evidence suggests that insiders exploit inside information. Unlike the cited studies which focus on a particular type of corporate news disclosure, Givoly and Palmon (1985) analyze the connection between insider trading and a large variety of news reports published in the Wall Street Journal subsequent to the insider trading day. They conclude that insiders do not seem to exploit inside information as their profits are not associated with the disclosure of specific news. Although the cited studies investigate the connection between insider trading and important corporate events, they have a decisive shortcoming. They are not able to link insider trading to a formal definition of inside information.

Our paper contributes to the literature in several ways. First, distinct from most studies on insider trading which focus on capital markets with a long history of insider regulation like Anglo-Saxon markets, we analyze the German market and thus provide evidence for a market with a relatively new legislation. Second, unlike prior studies which were unable to link insider trading to a formal definition of inside information, the fact that in Germany any inside information has to be disclosed via an ad-hoc news announcement offers a unique opportunity to evaluate whether corporate insiders front-run on inside information. Third, the attitude to exploit inside information may vary in different types of insiders.7 In Germany, three different groups of insiders have to report their trading records to the BaFin. In particular, members of the executive board (senior managers), which are involved in dayto-day business operations, are obliged to report their transactions to the BaFin. In addition, trading of members of the supervisory board (directors), which are usually not involved in day-to-day business operations, must also be reported to the BaFin. Last, the group of other insiders, which mainly consists of family members of senior managers and

\footnotetext{
7 A related question has been addressed under the label "information hierarchy hypothesis" by Seyhun (1986).
}

directors, has to reveal their trading in company's stock. To the best of our knowledge, the question whether the group of insiders which is best informed about company's prospects (i.e., senior managers) or the group which is probably least closely watched by the regulator (i.e., other insiders) is most active in trading on inside information, is basically unexplored.

With respect to our first research question which deals with the profitability of insider transactions, our results confirm the findings of prior study for Germany (see, e.g., Stotz 2006; Klinge, Seifert, and Stehle 2005; Betzer and Theissen 2005). Corporate insiders in Germany are able to identify profitable investment situations and thus realize substantial profits by trading in company's stock. Considering a 20-day period subsequent to the trading day, stocks traded by insiders are associated with significant cumulative abnormal returns (CARs): $4.38 \%$ for purchases and $-1.47 \%$ for sales. In consequence, German insiders earn higher profits compared to their Anglo-Saxon counterparts. ${ }^{8}$ Concerning our second research question, we find that insiders as a group seem to be engaged in the exploitation of inside information on the buy side as they earn significantly higher profits with those transactions which are shortly succeeded by an ad-hoc news disclosure of the respective company. With respect to our third research question, we document that trading activity prior to ad-hoc news announcements differs between the types of insiders. We find the group of directors to be most active in purchasing prior to ad-hoc news disclosures. In contrast, senior managers are less active in front-running on corporate news as they rarely purchase company's stock prior to an ad-hoc news disclosure. Finally, and most importantly, we show that directors and the group of other insiders earn exceptionally high profits with their purchases which front-run on corporate news disclosures and thus seem to exploit inside information. In contrast, senior managers seem to be aware that they are subject to the scrutiny of the supervisory authority as they do not realize superior returns with their rare transactions succeeded by a corporate news disclosure.

The remainder of this paper is structured as follows. Section 2 describes the legal background of insider

\footnotetext{
${ }^{8}$ See, e.g., Seyhun (1986) for the US and Friederich, Gregory, Matatko, and Tonks (2002) for the UK.
} 
trading in Germany, whereas section 3 addresses the database, provides some descriptive statistics, and discusses the methodology. Section 4 presents the results concerning our three research questions. Finally, section 5 concludes.

\section{Legal Background}

Since 1934, rule 10b-5 of the Security Exchange Act prohibits the exploitation of inside information by corporate insiders in the United States. A corresponding framework for the German capital market was passed as late as in 1994. Since then, § 14 WpHG (Security Trading Act) prohibits the exploitation and transmission of any inside information. According to $\S 14 \mathrm{WpHG}$ (Security Trading Act) “...it is prohibited to make use of inside information to acquire or dispose of insider securities for own account or for the account or behalf of a third party". ${ }^{9}$ However, as it might be hard to identify which information qualifies as an inside information on which trading is prohibited, $\S 13 \mathrm{WpHG}$ contains a legal definition of inside information. In particular, § $13 \mathrm{WpHG}$ defines inside information as “... any specific information about circumstances which are not subject to public knowledge (...), which, if it became publicly known, would likely have a significant effect on the stock exchange or market price of the insider security." Moreover, § $15 \mathrm{WpHG}$ requires exchange traded firms to disclose any inside information immediately to the public (ad-hoc announcement). § $15 \mathrm{WpHG}$ demands that an "immediate public disclosure is required from an issuer of financial instruments (...) regarding all inside information which directly concerns that issuer...”. Firms usually use special service providers which transmit the information to the market to fulfill these obligations.

In 2002, German insider surveillance was extended to corporate insiders' transactions in securities of their company (Directors' Dealings). Since July 1, 2002 , it is not only prohibited for corporate insiders to trade on inside information, but they also have to report trades in securities of their company. According to $\S 15 \mathrm{a}$ WpHG, members of the executive board and the supervisory board of exchange listed companies, as well as their family members are obliged to report transactions in companies' securities to

9 Please note that the WpHG is originally written in German. The English translations of paragraphs are taken from the homepage of BaFin. their company and to the German financial supervisory authority BaFin. Trading activities have to be reported without delay. Additionally, the firm has to publish the trading record on its web site or in a financial newspaper. Unlike in the US or UK, transactions carried out by former board members and large shareholders are not covered by the German insider law and therefore do not have to be reported. Furthermore, no report is required if the total amount of all transactions in a 30-day period does not exceed $€$ 25,000. In 2004, § 15 a was amended. Since October 30, 2004, persons discharging managerial responsibilities are also obliged to report their transactions. The reporting period for trading activities was specified to occur within five business days. The lower limit, which does not require a disclosure, was also reduced to $€ 5$,ooo per person in a calendar year. Furthermore, companies are now required to maintain lists of persons which have access to inside information ( $\$ 15 \mathrm{~b} \mathrm{WpHG}$ ).

\section{Data and Methodology}

\subsection{Data and descriptive Statistics}

Our empirical analysis covers insider transactions in German stocks between July 1, 2002 and April 30, 2005, which were reported to the BaFin. For each observation the respective database provided by the BaFin contains the company's name, the International Securities Identification Number (ISIN) of the reporting company, the name and type of the reporting insider (e.g., a member of the executive board), the trading and announcement day, the kind of transaction (e.g., a purchase of a stock), the number of securities traded, the stock price at which the transaction was executed, and the publishing media. To check and complement the database we match the information contained in the original database with statements from the company's annual reports and information published on the company's web site and other financial web sites..$^{10}$ The Deutsche Gesellschaft für Ad-hoc Publizität (DGAP) and euro-adhoc are the main providers which transmit ad-hoc news to the market. ${ }^{11}$ We use their databases to identify ad-hoc news releases subsequent to the

\footnotetext{
10 E.g., www.finanzen.net, www.insiderdaten.de.

11 According to Märzheuser and Gutzy (2004) the two data providers account for more than $95 \%$ of all ad-hoc news releases in Germany.
} 
trading day. We extract data on dividend and stock splits adjusted stock returns from Datastream. ${ }^{12}$ As our study focuses on the German legislation and the German market we only cover trades in stocks with a German ISIN (DE-ISIN). The original database contains 6,328 transactions carried out by insiders in 416 different firms. In a first step, we exclude duplicate and incomplete entries. Like previous studies on insider trading (e.g., Finnerty 1976; Gregory, Matatko, Tonks and Purkis 1994; Friederich, Gregory, Matatko, and Tonks 2002; Hillier and Marshall 2002; and Korczak, Korczak and Lasfer 2007), we focus on open-market transactions and exclude trades associated with corporate events. In particular, we exclude trades associated with exercise of options, security lending, changes in the capital structure, and takeover bids. In addition, transactions among insiders are also excluded. In 1,577 cases, the database includes two or more transactions of the same insider in the same stock on a given day. This is the case if an insider trades more than once on the same day or if the broker executes the order in two or more pieces. We aggregate these partial executions and multiple trades of the same individual in the same security on a given day. Furthermore, we dropped 136 observations due to incomplete return data. In 125 cases firms disclose ad-hoc news on the transaction day itself. As mentioned before, we use ad-hoc news disclosures to link insider trading to a potential exploitation of inside information. As we do not have information about the exact trading time, we could not determine whether the corporate insider traded prior to the respective ad-hoc news disclosure. Thus, these transactions were excluded from the sample. In order to avoid a double-counting of observations in each group of insiders which could trigger biased test statistics, we aggregate trades by different insiders on the same day. If two members of the executive board of BMW purchase the BMW stock on the same day (e.g., manager A purchases for 1 Mio. $€$ and manager $B$ purchases for 2 Mio. $€$ ), we treat the two original transactions as a new transaction with the combined transaction volume (e.g., 3 Mio. €). Employing this procedure, we lose 270 transactions in our final sample. In order to distinguish between groups, we finally exclude the 152 transactions

12 In particular, we use the data type $R I$ from Datastream which includes adjustments for dividends and stock splits. where more than one group of insiders traded company's stock on a specific day. E.g. if a member of the executive board and a member of the supervisory board trade in the same stock at the same day, both transactions are excluded from the final sample, since these transactions would distort inference about differences in CARs between groups.

Table 1 shows the generation of our final sample which consists of 2,657 insider transactions in 344 different firms. Thereof, 633 transactions are succeeded by a subsequent ad-hoc news disclosure in the following 20 trading days. With respect to the information revealed by public ad-hoc news disclosures, we find that 324 , and thus about $50 \%$ of the respective ad-hoc news deal with the release of quarterly and annual results. ${ }^{13}$ The remaining adhoc news refer to changes in the executive or supervisory board (44), changes in the lines of business operations like M\&A, business expansion or restructuring (73), changes in the capital structure of the company (72), or deal with other information like patents or, in case of pharmaceutical company, information about drug tests, changes in the ownership structure and litigation issues (120). The latter group also contains ad-hoc news with multiple reasons like, e.g., a combined release of an earnings announcement and a dismissal of an executive manager. Moreover, ad-hoc disclosures can either be scheduled or unscheduled. Whereas scheduled news like the release of earnings figures are known by market participants in advance, the remaining ad-hoc categories are typically unexpected and thus unscheduled. Table 2 shows that the number of transactions on the buy and sell side is rather balanced. In particular, purchases account for about $53 \%$ of all insider trades $(1,402$ out of 2,657$)$. With respect to the insider's position, we find members of the executive board and members of the supervisory board to trade most frequently. In particular, members of the executive board (members of the supervisory board) account for 749 (470) purchases and 468 (536) sales transactions. They correspond to about $46 \%$ (38\%) of all transactions. Consequently, the group of other insiders trades least frequently. Besides, the group of other insiders is the only group where the number of sales (251) exceeds the number of purchases (183).

\footnotetext{
13 Unlike in the UK in Germany there exists no trading ban prior to quarterly earnings announcements and the announcements of annual results.
} 


\section{Table 1: Description of Sample}

\begin{tabular}{|c|c|}
\hline Type of Transaction & Number of Transactions \\
\hline Insider Transactions reported to the BaFin & 7,543 \\
\hline Transactions in Foreign Corporations Dual Listed in Germany & $-1,215$ \\
\hline Insider Transactions in German Corporations & 6,328 \\
\hline Duplicate and Incomplete Entries & -104 \\
\hline \multicolumn{2}{|l|}{ Transactions concerning } \\
\hline Otions & -633 \\
\hline Security Lending and Donation & -115 \\
\hline Capital Structure & -246 \\
\hline Take-Over-Bids (acc. WpÜG) & -145 \\
\hline Others & -34 \\
\hline Transactions among Insiders & -134 \\
\hline Partial Execution and Multiple Transactions on a Given Day & $-1,577$ \\
\hline Incomplete or No Return Data & -136 \\
\hline News Disclosure at Transaction Day & -125 \\
\hline Transactions of Multiple Insiders, Group-Sprecific & -270 \\
\hline Transactions of Multiple Insiders, Multiple Groups & -152 \\
\hline Insider Transactions in the Final Sample & 2,657 \\
\hline Insider Transactions in the Final Sample with News Disclosure & 633 \\
\hline Release of Quarterly and Annual Results & 324 \\
\hline Changes in Executive or Supervisory Board & 44 \\
\hline Changes in Business Operations & 73 \\
\hline Changes in Capital Structure & 72 \\
\hline Others & 120 \\
\hline Insider Transactions in the Final Sample without News Disclosure & 2,024 \\
\hline
\end{tabular}

This table displays the number of transactions reported to the BaFin as well as the necessary corrections to obtain the final sample.

In total, insiders traded stocks for more than $€ 1.46$ billion. Interestingly, although they trade least frequently, the group of other insiders trade the highest volumes accounting for almost $41 \%$ of the total trading volume. In particular, their median (mean) transaction volume of $€ 70,268(€ 1,386,945)$ is above the average. Senior managers and directors trade smaller volumes. The median (mean) transaction volume for senior managers accounts for $€$ 27,600 $(€ 288,816)$ whereas the respective number for directors is $€ 23,265$ ( $€ 501,128)$. We also find that transaction volumes for purchases are on average smaller than for sales. The median (mean) transaction volume for sales of $€ 55,590(€ 784,956)$ is about two to three times larger than the volume for purchases $€ 19,350 €(€ 336,971)$. Consequently, although the number of sales is lower than the number of purchases, sales account for $68 \%$ of the total trading volume. Moreover, all groups of insiders are net sellers. As in most empirical studies the distribution of firm size is skewed. The mean market capitalization of a traded firm is $€ 1,644$ million and thereby highly exceeds the median market capitalization which equals $€ 43$ million.

\subsection{Methodology}

The purpose of our study is to measure the shortterm profits of insiders which trade in their company's stock. In accordance with most studies on insider trading, we measure these profits in an event study framework. We measure abnormal returns, i.e., returns that deviate from the normal return, subsequent to the insider trading day by applying standard event-study methodology outlined by For each transaction, calendar time is converted to event time by defining the day 
on which the insider executes the transaction as event day [o]. The estimation period encompasses the period from from [-199] to [-21], whereas the period from $[-20]$ to $[+20]$ is defined as the event period. for raw returns of each traded stock, we estimate OLS parameters in the estimation period while using the value-weighted $C D A X$ as the independent variable. This index consists of stocks listed on the

Table 2: Descriptive Statistics

\begin{tabular}{|c|c|c|c|}
\hline & Purchases & Sales & All Transactions \\
\hline Number of Traded Firms & 235 & 242 & 344 \\
\hline \multicolumn{4}{|l|}{ Number of Transactions } \\
\hline Total & 1,402 & 1,255 & 2,657 \\
\hline Members of Executive Board & 749 & 468 & 1,217 \\
\hline Members of Supervisory Board & 470 & 536 & 1,006 \\
\hline Other Insiders & 183 & 251 & 434 \\
\hline \multicolumn{4}{|c|}{ Mean Value of Transactions (in €thousand) } \\
\hline Total & 336,971 & 784,959 & 548,573 \\
\hline Members of Executive Board & 95,536 & 598,146 & 288,816 \\
\hline Members of Supervisory Board & 494,297 & 507,117 & 501,128 \\
\hline Other Insiders & 921,077 & $1,726,601$ & $1,386,945$ \\
\hline \multicolumn{4}{|c|}{ Median Value of Transactions (in €thousand) } \\
\hline Total & 19,350 & 55,590 & 30,000 \\
\hline Members of Executive Board & 15,634 & 69,650 & 27,600 \\
\hline Members of Supervisory Board & 16,535 & 34,280 & 23,265 \\
\hline Other Insiders & 49,350 & 80,200 & 70,268 \\
\hline \multicolumn{4}{|c|}{ Mean Market Capitalization (in Emillion) } \\
\hline Total & 2,024 & 1,220 & 1,644 \\
\hline Members of Executive Board & 2,057 & 440 & 1,435 \\
\hline Members of Supervisory Board & 1,398 & 1,410 & 1,405 \\
\hline Other Insiders & 3,495 & 2,269 & 2,786 \\
\hline \multicolumn{4}{|c|}{ Median Market Capitalization (in €million) } \\
\hline Total & 33 & 51 & 43 \\
\hline Members of Executive Board & 33 & 55 & 40 \\
\hline Members of Supervisory Board & 28 & 38 & 30 \\
\hline Other Insiders & 127 & 130 & 129 \\
\hline
\end{tabular}

This table presents descriptive statistics. In particular, information about the number of transactions, the mean (median) value of transactions and the mean (median) market capitalization of traded firms are displayed for the entire sample (all transactions) as well as for purchases and sales separately.

Abnormal returns for any given point in time and stock are defined as the difference between realized and normal returns. In order to estimate these expected normal returns, we choose the market model as surveyed by Brown and Warner (1985).14 First,

14 Please note that there exists a large number of models to estimate expected returns in event studies, like the constant mean return model, the market adjusted model or the FamaFrench 3 -factor model. However, for event studies analyzing the market reaction for just a few trading days the market model evolved as the standard in literature. E.g., the probably most prominent review articles on event study methodology (MacKinlay 1997 and Kothari and Warner 2007) recommend using the market model to estimate abnormal returns in short-run event studies. In addition to these methodological
Frankfurt Stock Exchange either in the Prime Standard or in the General Standard. ${ }^{5}$ Within the context of the market model, the normal return on each day in the event period is defined as the return of

considerations, the market model has also evolved as the standard model in the insider trading literature. In particular, the reference studies for Germany (Stotz 2006 and Betzer and Theissen 2005) use the market model to calculate cumulative abnormal returns.

15 The Prime Standard and the General Standard encompass all stocks listed in the regulated segment of the Frankfurt Stock Exchange. In addition, stocks listed in the Prime Standard have to fulfill higher transparency standards compared to stocks in the General Standard. 
the $C D A X$, adjusted by the estimated OLS parameters. As a consequence, abnormal returns derived from the market model are adjusted for individual stock's risk and the market return. To calculate the market reaction for more than one day we cumulate abnormal returns for the respective period.

In order to test for statistical significance of abnormal returns (ARs) and cumulative abnormal reurns (CARs) we first apply a parametric test, the standardized cross-sectional test proposed by Boehmer, Musumeci, and Poulsen (1991). This test has shown to be superior to the traditional $t$-test in the presence of event-induced increases in variances. However, parametric tests are sensitive to asymmetrically distributed returns (e.g., Brown and Warner 1985; and Corrado 1989). Thus, we also employ the nonparametric rank test based on Corrado (1989) to test for robustness. This type of test is correctly specified independently from the skewness of cross-sectional distribution of abnormal returns.

\section{Empirical Results}

\subsection{Insider Profits}

First, we address the question whether corporate insiders do earn abnormal returns by trading in their company's stock. Table 3 displays cumulative abnormal returns for distinct periods prior and subsequent to the insider trading day for purchases and sales, separately. It shows that corporate insiders actually do earn abnormal returns with their transactions.

Looking at the immediate stock price reaction associated with purchases, we find a moderate but insignificant $\mathrm{CAR}[\mathrm{O} ;+1]$ of $0.29 \%$. This immediate price reaction does not offer economically significant profits to insiders. Nevertheless, cumulative abnormal returns for longer periods are both statistically (according to the parametric standardized cross-sectional test by Boehmer, Musumeci, and Poulsen and the nonparametric rank test by Corrado) as well as economically significant. E.g., the cumulative abnormal return for the 20-day period following the trading day CAR $[0 ;+20]$ offers a decent $4.38 \%$ profit for the average insider transaction on the buy side. Thus, our result is in line with the findings of Stotz (2006) and Betzer and Theissen (2005). The latter study reports within a two-year investigation period from July 1, 2002 to June 30, 2004 , cumulative abnormal profits of $3.60 \%$ for a 20-day period subsequent to the trading day. We therefore confirm their finding that insider profits on the buy side are somewhat higher for the German market than those documented for the US and the UK. E.g., for the US, Seyhun (1986) reports a cumulated abnormal return for the 20-day period subsequent to the trading day of $1.10 \%$, whereas Friederich, Gregory, Matatko, and Tonks (2002) document a respective profit of $1.96 \%$ for the UK. Interestingly, from the perspective of the efficient market hypothesis, the price reaction is strikingly slow. In particular, after a period of five trading days subsequent to the insider transaction, only about $37 \%$ of the total increase within the 20-day event window is incorporated in stock prices $(1.62 \%$ compared to $4.38 \%$ ). The respective fraction for the tenday period is about $61 \%(\mathrm{CAR}[0 ;+10]$ equals $2.66 \%$ ), an almost linear adjustment to the cumulative abnormal return at the end of the event window. The rather slow adjustment in stock prices might be explained by legal aspects concerning reporting obligations. As discussed before, corporate insiders have to announce their trading records to the regulatory authority BaFin shortly after they have executed their order. Our data reveals that the median (mean) time period between the trading and the announcement day is three (nine) trading days for purchases. Thus, since insider transactions are closely followed by many investors, it may trigger a wave of transactions in the same direction by outsiders, thereby generating abnormal returns subsequent to the trading day. ${ }^{16}$

With respect to sale transactions, a different picture emerges. The immediate price reaction CAR $[0 ;+1]$ shows to be significantly positive with $0.26 \%$. Thus, stock prices do not reflect the negative information immediately. However, if one looks at the 20 trading days after the transaction, stocks sold by insiders drop by $-1.47 \%$. Although this moderate decline in stock prices does not necessarily yield economically significant profits for insiders when direct and indirect transactions costs are taken into account (see, e.g., Keim and Madhavan (1998); Berkowitz and Logue (2001), for the different components of transaction cost), the cumulative abnormal return is

\footnotetext{
16 Please note that the finding of a slow price adjustment is documented in several other studies. See, e.g., Givoly and Palmon (1985); Seyhun (1986); Bettis, Vickrey, and Vickrey (1997); Jeng, Metrick, and Zeckhauser (2003) for the US; Friederich, Gregory, Matatko, and Tonks (2002) for the UK; and Klinge, Seifert, and Stehle 2005; and Stotz (2006) for Germany.
} 
statistically significant according to the parametric as well as the non-parametric test.

Table 3: Cumulative Abnormal Returns for Purchases and Sales

\begin{tabular}{|c|c|c|c|c|c|c|c|c|}
\hline \multirow[b]{3}{*}{ CAR[20;-1] } & \multicolumn{4}{|c|}{ Purchase $(N=1402)$} & \multicolumn{4}{|c|}{ Sales $(N=1255)$} \\
\hline & Mean & & & SD & Mean & & & SD \\
\hline & $-0.75 \%$ & & +++ & 17.24 & $8.64 \%$ & **** & +++ & 29.81 \\
\hline CAR $[0 ; 1]$ & $0.29 \%$ & & & 5.97 & $0.26 \%$ & *** & & 8.41 \\
\hline CAR $[0 ; 5]$ & $1.62 \%$ & $* * *$ & +++ & 10.31 & $0.12 \%$ & & & 13.14 \\
\hline CAR $[0 ; 10]$ & $2.66 \%$ & $\%$ & +++ & 14.36 & $-0.84 \%$ & **** & +++ & 16.14 \\
\hline CAR $[0 ; 20]$ & $4.38 \%$ & $* * *$ & +++ & 18.92 & $-1.47 \%$ & $* * *$ & +++ & 24.35 \\
\hline
\end{tabular}

This table reports mean cumulative abnormal returns for distinct periods prior and subsequent to the day of insider trading [o]. ${ }^{* *}, * *,{ }^{*}$ indicate statistical significance at the 1\%-, 5\%-, $10 \%$-level (two-tailed test) according to standardized crosssectional test proposed by Boehmer, Musumeci, and Poulsen (1991). +++, ++, + indicate statistical significance at the 1\%-, 5\%-, $10 \%$-level according to the nonparametric rank test based on Corrado (1989).

The finding that insiders realize greater profits with their purchases than with their sales is also frequently documented in the literature. ${ }^{17}$ Unlike purchases, which are primarily motivated by the desire to realize profits, sales might be triggered by other considerations. First, basically only sales are motivated by diversification objectives and therefore might be non information-driven. For instance, many senior managers are strongly invested with their human capital in their firm and often have large holdings of company's stock. In addition, senior managers are increasingly compensated by stock option programs which allocate a substantial part of their personal wealth to their firm. Our data reveal that corporate insiders reduce their exposure in the company after substantial price increases. In particular, insiders sell stocks which yield a highly sig-

17 See, e.g., Bettis Vickrey, and Vickrey (1997); Lakonishok and Lee (2001); and Jeng, Metrick, and Zeckhauser (2003) for the US; Friederich, Gregory, Matatko, and Tonks (2002) for the UK. In contrast, almost symmetrical profits on both buy and sell side are found by, e.g., Seyhun (1986); Givoly and Palmon (1985); Klinge, Seifert, and Stehle (2005); Betzer and Theissen (2005); and Stotz (2006). In particular, Betzer and Theissen (2005) find an almost symmetrical market reaction on the buy and sell side for the German market. In particular, they report a CAR[0;20] of $-3.53 \%$. Differing results could, however, be explained by a differing sample period as well as differences in analyzed transactions as Betzer and Theissen (2005) also include sale transactions from exercised stock options. nificant positive $\operatorname{CAR}[-20 ;-1]$ of $8.64 \%$ in the 20 trading days prior to the insider trading day. Thus, corporate insiders seem to time their selling after significant price run-ups. Second, another non information-driven reason which is more prevalent for sales than for purchases is liquidity. If a corporate insider wants to buy a new mansion or Learjet, she might prefer to sell some corporate stocks, especially if they recently went up in prices. Moreover, sales may be motivated by tax considerations.

\subsection{Do Corporate Insiders Exploit Inside Information?}

A decisive prerequisite to answer the question whether corporate insiders exploit inside information is the identification of those transactions which may exploit inside information. In an ideal world, one could directly observe the information set of an insider at the transaction day. Unfortunately, in reality this information is unobservable.

Thus, one has to find an observable proxy for inside information. Probably the best way to formally identify trades which are likely to be based on inside information, is to link corporate insider trading to ad-hoc news disclosures subsequent to the insider trading day. As mentioned before, German firms are required to disclose any inside information (§ 13 $\mathrm{WpHG}$ ) to the public via an ad-hoc announcement (§ $15 \mathrm{WpHG}$ ). Those ad-hoc announcements deal with corporate events which are likely to have a significant effect on the stock price like, e.g., changes in the executive board structure, earnings announcements, and merger activities. Thus, insider trading prior to ad-hoc news disclosures is a first indicator for an exploitation of inside information since corporate insiders are likely to know at least the tendency of the ad-hoc news prior to theirdisclosure. For instance, it is hard to believe that a senior manager is not continuously informed about the performance of her firm or is not involved in and informed about takeover or merger proceedings.

Table 4 displays for each group of insiders the group-specific fraction of trades with subsequent 
ad-hoc news disclosure in the suspected period $[+1 ;+20]$, separately. In addition, the respective fraction for the total sample and the difference between the groups and the total sample are displayed in the table. Panel $A$ shows the respective statistics for purchases, whereas Panel $B$ refers to sales. front-running transactions. On the other hand, insiders could exploit inside information even though they trade less frequently prior to ad-hoc news. For instance, an insider could refrain from trading prior to the subsequent release of ad-hoc news disclosures which have low value but front-run

\section{Table 4: Fraction of Transactions with Subsequent Ad-hoc News Disclosure, by Type of In-} sider and Compared to the Total Sample

Panel A. Purchases $(N=1402)$

\begin{tabular}{|c|c|c|c|}
\hline & $\begin{array}{c}\text { Members of } \\
\text { Executive Board }\end{array}$ & $\begin{array}{c}\text { Members of } \\
\text { Supervisory Board }\end{array}$ & Other Insiders \\
\hline Percentage of Purchases with News in Group (1) & $20.16 \%$ & $26.38 \%$ & $23.50 \%$ \\
\hline Percentage of Purchases with News in Total Sample (2) & $22.68 \%$ & $22.68 \%$ & $22.68 \%$ \\
\hline$(1)-(2)$ & $-2.52 \% *$ & $3.70 \% *$ & $0.82 \%$ \\
\hline \multicolumn{4}{|l|}{ Panel B. Sales $(N=1255)$} \\
\hline & $\begin{array}{c}\text { Members of } \\
\text { Executive Board }\end{array}$ & $\begin{array}{c}\text { Members of } \\
\text { Supervisory Board }\end{array}$ & Other Insiders \\
\hline Percentage of Sales with News in Group (1) & $23.50 \%$ & $25.56 \%$ & $27.09 \%$ \\
\hline Percentage of Sales with News in Total Sample (2) & $25.10 \%$ & $25.10 \%$ & $25.10 \%$ \\
\hline$(1)-(2)$ & $-1.60 \%$ & $0.46 \%$ & $1.99 \%$ \\
\hline
\end{tabular}

This table reports the distribution of purchases and sales for the total sample and for different types of insiders separately. (1) displays for the respective group of insider the fraction of transactions with a subsequent news disclosure to the total number of transactions by the respective group in the period $[+1 ;+20]$. Accordingly, (2) gives the respective fraction for the total sample. ***, **,* indicate statistical significance at the 1\%-, 5\%-,10\%-level according to the binomial test.

As far as purchases are concerned, we find that a fraction of about $22.68 \%$ (318 out of 1,402) of all transactions is succeeded by an ad-hoc disclosure in the suspected period. Looking at the different groups of insiders, we find that senior managers are least often engaged in transactions which are succeeded by corporate news disclosures. The fraction of purchases with a subsequent ad-hoc news disclosure is only $20.16 \%$. A different picture emerges for directors. With respect to trading prior to ad-hoc news disclosures, $26.38 \%$ of the purchases carried out by directors are executed shortly prior to an adhoc disclosure. In contrast to the findings for purchases, we do not find any group of insiders to be particularly engaged in trading prior to ad-hoc news disclosure on the sell side.

However, trading prior to ad-hoc news disclosures is neither a necessary nor a sufficient condition to evaluate whether corporate insiders exploit inside information. On the one hand, insiders could trade rather frequently prior to ad-hoc disclosures which, however, have a negligible value. In this case, corporate insiders should not realize superior profits with on rare and exceptionally relevant information. If this scenario occurs, insiders would realize superior profits even though they do not trade particularly often prior to ad-hoc news disclosures.

Thus, our criterion to detect an exploitation of inside information refers to the profitability of trading. If insiders systematically purchase stocks prior to positive ad-hoc news and sell stocks prior to negative ad-hoc news, they should, ceteris paribus, earn higher profits with these transactions compared to the remaining transactions. On the contrary, if insiders do not condition their trading decisions on the information content of subsequent adhoc news releases and, thus, purchase stocks as often prior to good as before bad news, ${ }^{18}$ the average profits of transactions with subsequent ad-hoc news disclosure should be similar to profits of transactions without subsequent news disclosure. As a consequence, we feel confident to accuse insiders of

18 Korczak, Korczak, and Lasfer (2007) report for a large sample of news releases by UK firms that positive news occurs as frequently as negative news. $T$ 
exploiting inside information if transactions of insiders, which are succeeded by an ad-hoc news disclosure of the respective company in the subsequent 20 trading days, are associated with higher profits compared to the remaining transactions without an ad-hoc news disclosure. In the following, we will refer to those transactions as unethical.

\section{Univariate Analyses}

Table 5 (see following page) displays cumulative abnormal returns for several short-term periods subsequent to the insider trading day for purchases (Panel $A$ ) and sales (Panel B). The first vertical panel refers to all transactions. Herein, the first column addresses transactions with an ad-hoc news disclosure in the subsequent 20 trading days (News). The second column refers to transactions without a subsequent ad-hoc news disclosure (No News) and the third vertical panel displays the difference in means between the first two columns. The second through fourth vertical panels display group-specific results. The first columns in those panels display the mean returns for transactions with a subsequent ad-hoc news disclosure for each group of insiders, whereas the second column displays the difference in means between the respective group-specific returns and the profits of all transactions without a subsequent news disclosure.

With respect to purchases, we find that insiders as a group earn particularly high profits with their front running transactions. Corporate insiders earn an abnormal profit of $7.38 \%$ within the 20 trading days after front-running on ad-hoc news disclosures. ${ }^{19}$ For transactions without a subsequent ad-hoc news disclosure, we document a respective value of mere $3.50 \%$. Moreover, the difference in mean profits between trades which front-run on corporate news disclosure and the remaining transactions without a subsequent ad-hoc news disclosure is statistically significant starting with CAR $[0 ;+5]$ onward. Thus, corporate insiders as a group seem to purchase company's stock systematically prior to positive

\footnotetext{
19 Our results further reveal that trading prior to both scheduled and unscheduled ad-hoc news is associated with high returns. In particular, trading prior to scheduled (unscheduled) news is associated with a cumulative abnormal return in the period $[0 ;+20]$ of $5.13 \%(9.39 \%)$, Please note that Betzer and Theissen (2005) document a similar return for trading prior to scheduled news. In particular, they report $5.26 \%$ for purchases which are executed two months prior to an annual or interim earnings announcement, and the month prior to a quarterly earnings announcement (blackout period according to UK legislation).
}

news. This reasoning is also supported if one analyzes the abnormal returns on the disclosure day of the ad-hoc news subsequent to insider purchases. Whereas $62.58 \%$ of the ad-hoc news subsequent to purchases of corporate insiders is associated with positive abnormal returns, only a minority of $37.42 \%$ trigger a negative market reaction at the day of the ad-hoc news disclosure.

Similar to our findings for purchases, profits associated with sale transactions which front-run on corporate news are considerably higher for all analyzed periods. E.g., according to the first column of Panel $B$ of Table 5 the CAR[0;+20] is double the magnitude for sales which front-run on subsequent news releases compared to the remaining transactions. However, the differences in means between sale transactions with and without subsequent news disclosure are statistically insignificant. This might be caused by abnormal returns on the disclosure day of the ad-hoc news subsequent to insider sales. In particular, the number of positive and negative market reactions is rather balanced as $53.65 \%$ trigger a positive and $46.35 \%$ trigger a negative market reaction.

Given the evidence that insiders as a group seem to exploit inside information, we are curious which type of corporate insider is particularly engaged in exploiting inside information. To put things differently, we want to figure out whether it is primarily the group of members of the executive board (executive managers), the group of members of the supervisory board (directors), or the group of other corporate insiders which tend to trade in an unethical manner. This question is basically an empirical one, since two opposite effects are simultaneously at work.

On the one hand, senior managers which are involved in day-to-day business operations have superior access to inside information compared to the two other groups of insiders. Thus, concerning the criterion of accessibility to inside information, senior managers might be most tempted to front-run on important corporate news. On the other hand, one has to be aware that senior managers are also in the spotlight of public attention, and, more importantly, probably under particular scrutiny of the regulatory authority. Hence, the fear of prosecution might weaken their intention to exploit inside information. With respect to the two other groups of insiders, monitoring might be less pronounced. Consequently, directors and other insiders might be 
more bold to trade on their inside information as they do not fear a thorough inspection of their trading records. content of the subsequently released ad-hoc news. We get a similar result concerning the group of other insiders. Even though other insiders do not

Table 5: Cumulative Abnormal Returns, by Ad-hoc News Disclosure After Transaction

\begin{tabular}{|c|c|c|c|c|c|c|c|c|c|}
\hline \multicolumn{10}{|c|}{ Panel A. Purchases } \\
\hline & \multicolumn{3}{|c|}{ All Transactions } & \multicolumn{2}{|c|}{ Members of Executive Board } & \multicolumn{2}{|c|}{ Members of Supervisory Board } & \multicolumn{2}{|c|}{ Other Insiders } \\
\hline & $\begin{array}{c}\text { News } \\
N=318\end{array}$ & $\begin{array}{l}\text { No News } \\
N=1084\end{array}$ & $\begin{array}{l}\text { Difference } \\
\text { in means }\end{array}$ & $\begin{array}{c}\text { News } \\
N=151\end{array}$ & $\begin{array}{c}\text { Difference } \\
\text { to No News } \\
N=1084\end{array}$ & $\begin{array}{c}\text { News } \\
N=124\end{array}$ & $\begin{array}{c}\text { Difference } \\
\text { to No News } \\
N=1084\end{array}$ & $\begin{array}{l}\text { News } \\
N=43\end{array}$ & $\begin{array}{c}\text { Difference } \\
\text { to No News } \\
N=1084\end{array}$ \\
\hline CAR $[0 ; 1]$ & $0.28 \%$ & $0.30 \%$ & $-0.02 \%$ & $-0.16 \%$ & $-0.46 \%$ & $0.63 \%$ & $0.33 \%$ & $0.81 \%$ & $0.51 \%$ \\
\hline $\operatorname{CAR}[0 ; 5]$ & $2.73 \% * * *$ & $1.30 \%$ *** & $1.43 \%$ & $0.92 \%$ & $0.38 \%$ & $4.71 \% * *$ & $3.41 \%: 11$ & $3.39 \% * * *$ & $2.09 \%$ \\
\hline $\mathrm{CAR}[0 ; 10]$ & $4.96 \% * * *$ & $1.99 \% * * *$ & $2.97 \%+++$ & $1.51 \%$ & $0.48 \%$ & $8.52 \% * * *$ & $6.53 \%+++$ & $6.85 \% * * *$ & $4.86 \%++$ \\
\hline CAR $[0 ; 20]$ & $7.38 \%$ *⿻三丨 & $3.50 \%$ 䖴粈 & $3.88 \%$ & $2.61 \%$ & $-0.89 \%$ & $12.96 \%$ *** & $9.46 \% \quad 11$ & 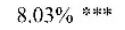 & $4.53 \%$ । \\
\hline \multicolumn{10}{|c|}{ Panel B. Sales } \\
\hline & \multicolumn{3}{|c|}{ All Transactions } & \multicolumn{2}{|c|}{ Members of Executive Board } & \multicolumn{2}{|c|}{ Members of Supervisory Board } & \multicolumn{2}{|c|}{ Other Insiders } \\
\hline & $\begin{array}{c}\text { News } \\
N=315\end{array}$ & $\begin{array}{l}\text { No News } \\
N=940\end{array}$ & $\begin{array}{c}\text { Difference } \\
\text { in means }\end{array}$ & $\begin{array}{c}\text { News } \\
N=110\end{array}$ & $\begin{array}{c}\text { Difference } \\
\text { to No News } \\
N=940\end{array}$ & $\begin{array}{c}\text { News } \\
N=137\end{array}$ & $\begin{array}{c}\text { Difference } \\
\text { to No News } \\
N=940\end{array}$ & $\begin{array}{c}\text { News } \\
N=68\end{array}$ & $\begin{array}{c}\text { Difference } \\
\text { to No News } \\
N=940\end{array}$ \\
\hline $\operatorname{CAR}[0 ; 1]$ & $0.24 \% *$ & $0.27 \% * *$ & $-0.03 \%$ & $0.59 \% *$ & $0.32 \%$ & $-0.36 \%$ & $-0.63 \%$ & $0.91 \%$ & $0.64 \%$ \\
\hline $\mathrm{CAR}[0 ; 5]$ & $-0.19 \%$ & $0.22 \%$ & $-0.41 \%$ & $-0.46 \%$ & $-0.68 \%$ & $0.51 \%$ & $0.29 \%$ & $-1.15 \%$ & $-1.37 \%$ \\
\hline $\operatorname{CAR}[0 ; 10]$ & $-1.08 \%$ & $-0.76 \%$ 米米半 & $-0.32 \%$ & $-0.63 \%$ & $0.13 \%$ & $-0.70 \%$ & $0.06 \%$ & $-2.51 \%$ & $-1.75 \%$ \\
\hline CAR $[0 ; 20]$ & $-2.41 \% * *$ & $-1.16 \% * * *$ & $-1.25 \%$ & $-2.43 \% * *$ & $-1.27 \%$ & $-2.10 \%$ & $-0.94 \%$ & $-3.00 \%$ & $-1.84 \%$ \\
\hline
\end{tabular}

This table displays mean cumulative abnormal returns for distinct periods subsequent to the day of insider trading [o] separated by whether ad-hoc news were disclosed during the 20 trading days subsequent to the transaction and by type of insider. ****, ***, * indicate statistical significance at the 1\%-, 5\%-, 10\%-level (two-tailed test) that the mean cumulative abnormal return is different from zero according to the cross-sectional rank test proposed by Boehmer, Musumeci, and Poulsen (1991). With respect to comparisons of cumulative abnormal returns between subgroups, +++, ++, + indicate statistical significance at the 1\%-, 5\%-, 10\%-level according to the two-sample t-test.

Table 5 provides interesting empirical evidence concerning the trading behavior of different groups of insiders. On the buy-side, we find that senior managers do not seem to be engaged in frontrunning on inside information. Not only do they trade least frequently prior to ad-hoc disclosures, but senior managers also do not realize superior profits. Particularly, the CAR[o;+20] equals $2.61 \%$ for purchases with subsequent news disclosures in the 20 trading days after the insider's trading day, whereas the remaining transactions yield a profit of $3.50 \%$. However, from a statistical point of view, the difference in means of $-0.89 \%$ is not statistically different from zero.

A very different picture emerges when we look at directors' purchases. In addition to their significantly higher trading frequency prior to ad-hoc news releases, they seem to trade on valuable information. E.g., the CAR $[0 ;+20]$ for front-running purchases for directors equals $12.96 \%$. The difference in mean profits of front-running transactions compared to no news transactions is statistically significant for all analyzed periods from $[0 ;+5]$ onwards and equals $9.46 \%$ for the period $[0 ;+20]$. This indicates that directors trade on the information frequently front-run on corporate news, they do realize exceptional profits with those transactions. In particular, they realize a handsome profit with a $\mathrm{CAR}[0 ;+2 \mathrm{O}]$ of $8.03 \%$ with their front-running purchases. Additionally, the difference in means compared to the no news transactions shows to be $4.53 \%$, a profit significant on the $5 \%$-level.

Given that other insiders seem to exploit inside information, a natural question arises. How does the group of other insider split between family members of executive managers and family members of directors? For purchases, the 183 transactions of other insiders are anything but uniformly distributed across the two remaining insider groups. Only 39 transactions of other insiders could be traced to a relative of a member of the executive board, whereas the majority of 116 transactions can be directed to a member of the supervisory board. The remaining 28 transactions could not be unambiguously assigned to one group or the other. Although, family members of executive managers do not trade very often, they nonetheless seem to exploit inside information with their 12 transactions which are succeeded by an ad-hoc disclosure. Looking at the 20-day period following the transaction 
day, family members of executive managers earn $8.57 \%$ with their transactions succeeded by an adhoc news disclosure. Concerning family members of directors, results do not differ much whether the insider traded by himself or through a family member. In particular, in the 20 trading days subsequent to the insider trading day, family members of directors earn $8.24 \%$ with those transactions which front-run on corporate news.

Regarding sales transactions, we find no specific group of insiders to be severely engaged in exploiting inside information. Although according to Table 5 , we predominately find the profits associated with sales which front-run on corporate news to be higher for executive managers and directors, differences in means of abnormal returns are not statistically significant.

\section{Multivariate Analyses}

In order to test for robustness, we complement our univariate analysis by performing multivariate regressions. Basically, we want to verify the conjecture that higher profits of front-running transactions on the buy side are indeed driven by subsequent ad-hoc news disclosures. In contrast, they could be triggered solely by common characteristics of the transaction not accounted for in univariate group comparisons. Thus, Table 6 (on page 15) displays multivariate regression results for two models on the dependent variables CAR $[0 ;+10]$ and CAR $[0 ;+20]$. The most important independent variable is the dummy variable NEWS, which equals one if the company discloses ad-hoc news in the period $[+1 ;+20]$ subsequent to the trading day and zero otherwise. The first model includes besides a number of control variables listed below the NEWS variable exclusively, which - in this model - measures the effect of a subsequent ad-hoc disclosure on cumulative abnormal returns. The second model differs from the first one as it additionally includes two interaction terms in order to reveal differences between the three groups of insiders. The two interactions terms are (i) NEWS, multiplied by a dummy variable indicating whether an insider is a member of the supervisory board (SUPERVISORY BOARD), and (ii) NEWS multiplied by a dummy variable indicating whether an insider is a member of the group of other insiders (OTHER INSIDERS). One can interpret the respective coefficients of the interaction terms as the differential effect for transactions (i) of directors and (ii) other insiders com- pared to transactions of senior managers for the sub-sample of front-running transactions. Finally, the coefficient on NEWS indicates the differential effect of front-running transactions by senior managers compared to the remaining transactions without a subsequent news disclosure.

In order to take common characteristics of a transaction into account, we include a set of control variables concerning trade-specific factors as well as company-specific factors. ${ }^{20}$ Concerning tradespecific factors, we construct several control variables which relate to characteristics of the transaction. First, e.g., Seyhun (1992); Bettis, Vickrey, and Vickrey (1997); and Fidrmuc, Georgen, and Renneboog (2006) have shown that relatively large volume trades yield higher returns than small volumes. Thus, in order to control for the trading volume we construct the variable TRADING_INTENSITY, which is defined as the trading volume of the respective transaction divided by the market value of the firm on the trading day. Second, we control for the delay in reporting. We expect that corporate insiders are more reluctant to report their trades in a timely manner for those trades which are based on valuable information. Thus, we include the variable REPORTING_DELAY, which counts the number of trading days between the transaction day and the reporting day. Third, Seyhun (1986) has shown that insider profits are negatively related to prior performance. Because of this evidence and due to our finding that insiders are contrarian investors, ${ }^{21}$ we include the variable MOMENTUM which measures the cumulative abnormal return prior to the trading day in the period CAR[-20;-1]. Fourth, if several insiders trade the same stock on a particular date, this might reveal a stronger signal about the insiders' estimation of the company's prospects. Accordingly, Fidrmuc, Georgen, and Renneboog (2006) have shown that the market reaction of insider transactions depends on the number of simultaneously acting traders. Therefore, we introduce the dummy variable MULTIPLE_TRADERS, which equals one if more than one insider traded the stock on the same day and zero otherwise. Fifth, we con-

\footnotetext{
20 With respect to both categories we include foremost those control variables which have shown to be significant determinants in prior research.

21 A contrarian investor is someone who purchases after a recent decline in stock prices and sells after a recent increase in stock prices. As one can see from Table 3 , the tendency to act as a contrarian investor is more pronounced on the sell side.
} 
trol for structural changes according to the changing legal environment within the sample period. The dummy variable LEGISLATION equals one if the transaction takes place after the reform of insider trading regulations on October 30, 2004 and zero otherwise.

We also include a set of control variables referring to company characteristics. First, since several studies (e.g., Seyhun 1986 and Gregory, Matatko, Tonks, and Purkis 1994) have shown that profits are higher for smaller firms, we define the variable SIZE, which equals the natural logarithm of the market value of a firm at the beginning of the respective calendar year, to control for the firm's size. Second, our results might be triggered by thinly traded stocks. Thus, we include the dummy variable PENNY_STOCK, which equals one if the respective stock is traded at a price below one euro at the day of the transaction and zero otherwise. Third, previous research has documented a decisive role of the price-to-book ratio in explaining (abnormal) returns (see, e.g., Fama and French 1993; and Fama and French 1995). Thus, we include the variable PRICE_TO_BOOK, which equals the market value compared to the book value of a firm at the transaction day. Finally, Fidrmuc, Georgen, and Renneboog (2006) and Betzer and Theissen (2005) show that profits for corporate insiders and the market reaction to the announcement of insider transactions depend on the firms' ownership structure. Therefore we include two variables to control for the ownership structure and the corporate governance structure of the firm. The variable FREEFLOAT proxies the level of management autonomy and is defined as the fraction of shares in the free float as opposed to shares held by block holders. Moreover, we control for dominating shareholders including the dummy variable BLOCKHOLDER, which equals one if the respective company has a majority shareholder (i.e., a single shareholder controls more than 50 percent of the voting shares) and zero otherwise. In order to evaluate whether the size of both boards have an influence on insider profits, we include the variable SUPERVISORY BOARD_SIZE (EXECUTIVE BOARD_SIZE), which represents the number of board members in each board.

As far as purchases are concerned, the first models in Table 6 (see following page) which exclude the interaction terms confirm our univariate finding that corporate insiders as a group earn exceptional profits by front-running on corporate news. In par- ticular, the coefficients for the dummy variable NEWS are positive and statistically significant for both periods. Concerning the control variables, the signs of the coefficients are predominantly in line with our predictions. Interestingly, however, the coefficient on MULTIPLE_TRADES is significantly negative in both regressions. Thus, insiders earn mediocre profits with those transactions where more than one insider traded a stock at the same time. The finding contradicts the prediction that the information value might be larger if a bunch of insider flock together in their trading decision but confirm the results of Betzer and Theissen (2005) who report a similar finding. Moreover, the size of the boards does not affect cumulative abnormal returns in a systematic way. Regarding sale transactions, multivariate regression support the univariate finding that corporate insiders as a group do not earn significantly higher profits with front-running transactions. The results displayed in Panel $B$ of Table 6 show the respective coefficients on the variable NEWS to be negative but insignificant.

Multivariate regression analyses conducted in the second models support our findings concerning the different types of insiders. Looking at members of the executive board, regression results emphasize that members of the executive board do not seem to front-run on valuable ad-hoc news. As displayed in Panel A of Table 6, the coefficient of NEWS in the second model, which measures the differential effects of front-running transaction by members of the executive board compared to the remaining transactions (No News), is insignificant.

According to the two remaining groups of insiders, multivariate regression results confirm the univariate conjunction that these groups seem to exploit inside information. As far as directors are concerned, the coefficient on the respective interaction term is highly significant, indicating that directors earn more with their front running transactions than executive managers.

The effect compared to the no news transactions is captured by the sum of the coefficients on NEWS and NEWS*SUPERVISORY BOARD. In particular, the sum of coefficients shows to be significant on the 1\%-level for both analyzed periods. Analogously, the finding that front-running transactions of other insiders yield exceptionally high profits is also supported by multivariate results for the period $[0 ;+10]$, but not for the longer event window. 
Table 6: Cumulative abnormal returns, by ad-hoc news disclosure after transaction

\begin{tabular}{|c|c|c|c|c|c|c|c|c|}
\hline \multicolumn{9}{|l|}{ Panel A. Purchases } \\
\hline & \multicolumn{2}{|c|}{ CAR $[0 ; 10]$} & \multicolumn{2}{|c|}{$\operatorname{CAR}[0 ; 10]$} & \multicolumn{2}{|c|}{$\operatorname{CAR}[0 ; 20]$} & \multicolumn{2}{|c|}{$\operatorname{CAR}[0 ; 20]$} \\
\hline & Coefficient & $t$-stat & Coefficient & $t$-stat & Coefficient & $t$-stat & Coefficient & $t$-stat \\
\hline $\mathrm{C}$ & 0.0381 & $2.77 * * *$ & 0.0408 & $2.93 * * *$ & 0.0680 & $3.53 * * *$ & 0.0717 & $3.68 * * *$ \\
\hline NEWS & 0.0231 & $2.53 * *$ & -0.0014 & -0.13 & 0.0327 & $2.67 * * *$ & -0.0028 & -0.21 \\
\hline NEWS*SUPERVISORY_BOARD & & & 0.0490 & $2.62 * * *$ & & & 0.0832 & $3.30 * * *$ \\
\hline NEWS*OTHER_INSIDERS & & & 0.0440 & $2.21 * *$ & & & 0.0317 & 1.30 \\
\hline TRADING_INTENSITY & 0.1624 & 0.72 & 0.1650 & 0.73 & 0.3099 & 0.86 & 0.3264 & 0.90 \\
\hline REPORTING_DELAY & 0.0000 & 0.68 & 0.0000 & 0.61 & 0.0001 & 0.86 & 0.0001 & 0.84 \\
\hline MOMENTUM & 0.0556 & 1.06 & 0.0545 & 1.05 & 0.0614 & 0.94 & 0.0597 & 0.93 \\
\hline NUMBER_OF_TRADERS & -0.0178 & $-3.67 * * *$ & -0.0209 & $-3.86 * * *$ & -0.0296 & $-4.79 * * *$ & -0.0357 & $-5.10 * * *$ \\
\hline LEGISLATION & 0.0078 & 0.90 & 0.0056 & 0.64 & 0.0192 & 1.41 & 0.0184 & 1.31 \\
\hline SIZE & -0.0058 & $-1.79 *$ & -0.0064 & $-1.99 * *$ & -0.0082 & $-1.97 * *$ & -0.0090 & $-2.18 * *$ \\
\hline PENNY_STOCK & 0.2164 & $3.75 * * *$ & 0.2088 & $3.65 * * *$ & 0.2703 & $3.41 * * *$ & 0.2567 & $3.31 * * *$ \\
\hline PRICE_TO_BOOK & -0.0018 & $-4.45 * * *$ & -0.0016 & $-4.09 * * *$ & -0.0023 & $-3.48 * * *$ & -0.0019 & $-3.29 * * *$ \\
\hline FREEFLOAT & 0.0005 & $2.23 * *$ & 0.0005 & $2.28 * *$ & 0.0007 & $2.40 * *$ & 0.0007 & $2.48 * *$ \\
\hline BLOCKHOLDER & -0.0082 & -0.94 & -0.0081 & -0.92 & -0.0315 & $-2.96 * * *$ & -0.0321 & -2.99 *** \\
\hline SUPERVISORY BOARD_SIZE & 0.0006 & 0.45 & 0.0006 & 0.50 & 0.0003 & 0.19 & 0.0006 & 0.34 \\
\hline EXECUTIVE BOARD_SIZE & 0.0004 & 0.15 & 0.0011 & 0.38 & 0.0037 & 1.00 & 0.0047 & 1.27 \\
\hline Adj. $R^{2}$ & 0.1293 & & 0.1352 & & 0.1404 & & 0.1491 & \\
\hline Prob(F-statistic) & 0.1211 & & 0.1258 & & 0.1323 & & 0.1399 & \\
\hline$N$ & 1,400 & & 1,400 & & 1,400 & & 1,400 & \\
\hline \multicolumn{9}{|l|}{ Panel B. Sales } \\
\hline & \multicolumn{2}{|c|}{ CAR $[0 ; 10]$} & \multicolumn{2}{|c|}{$\operatorname{CAR}[0 ; 10]$} & \multicolumn{2}{|c|}{$\operatorname{CAR}[0 ; 20]$} & \multicolumn{2}{|c|}{$\operatorname{CAR}[0 ; 20]$} \\
\hline & Coefficient & $t$-stat & Coefficient & $t$-stat & Coefficient & $t$-stat & Coefficient & $t$-stat \\
\hline $\mathrm{C}$ & -0.0669 & $-3.69 * * *$ & -0.0694 & $-3.84 * * *$ & -0.1287 & $-4.98 * * *$ & -0.1300 & $-5.09 * * *$ \\
\hline NEWS & -0.0017 & -0.14 & 0.0066 & 0.49 & -0.0098 & -0.56 & 0.0050 & 0.29 \\
\hline NEWS*SUPERVISORY_BOARD & & & -0.0056 & -0.25 & & & -0.0228 & -0.68 \\
\hline NEWS*OTHER_INSIDERS & & & -0.0276 & -1.24 & & & -0.0228 & -0.75 \\
\hline TRADING_INTENSITY & 0.3613 & $2.02 * *$ & 0.3593 & $2.00 * *$ & 0.8158 & $1.75 *$ & 0.8098 & $1.74 *$ \\
\hline REPORTING_DELAY & 0.0004 & 1.04 & 0.0004 & 1.20 & 0.0008 & 1.32 & 0.0009 & 1.38 \\
\hline MOMENTUM & 0.0258 & 0.71 & 0.0255 & 0.70 & 0.1025 & $1.84 *$ & 0.1020 & $1.83 *$ \\
\hline NUMBER_OF_TRADERS & 0.0152 & 1.27 & 0.0163 & 1.34 & 0.0236 & $1.91 *$ & 0.0237 & $1.91 *$ \\
\hline LEGISLATION & 0.0262 & $2.47 * *$ & 0.0276 & $2.60 * * *$ & 0.0342 & $2.21 * *$ & 0.0351 & $2.28 * *$ \\
\hline SIZE & 0.0021 & 0.37 & 0.0024 & 0.43 & 0.0143 & $1.86 *$ & 0.0143 & $1.82 *$ \\
\hline PENNY_STOCK & 0.0143 & 0.37 & 0.0131 & 0.34 & 0.1571 & $2.53 * *$ & 0.1580 & $2.56 * *$ \\
\hline PRICE_TO_BOOK & -0.0059 & -1.43 & -0.0056 & -1.41 & -0.0017 & -0.28 & -0.0014 & -0.24 \\
\hline FREEFLOAT & 0.0003 & 1.19 & 0.0003 & 1.18 & 0.0000 & 0.10 & 0.0001 & 0.13 \\
\hline BLOCKHOLDER & 0.0174 & 1.33 & 0.0165 & 1.25 & 0.0116 & 0.66 & 0.0113 & 0.63 \\
\hline SUPERVISORY BOARD_SIZE & 0.0013 & 0.84 & 0.0012 & 0.76 & 0.0014 & 0.67 & 0.0016 & 0.74 \\
\hline EXECUTIVE BOARD_SIZE & -0.0002 & -0.05 & -0.0005 & -0.10 & -0.0086 & -1.39 & -0.0090 & -1.46 \\
\hline Adj. $R^{2}$ & 0.0247 & & 0.0256 & & 0.0806 & & 0.0811 & \\
\hline Prob(F-statistic) & 0.0144 & & 0.0138 & & 0.0709 & & 0.0699 & \\
\hline$N$ & 1,250 & & 1,250 & & 1,250 & & 1,250 & \\
\hline
\end{tabular}

This table shows results based on multivariate OLS regressions of CAR[o;10] and CAR[o;2O] on potential determinants. The independent variables are defined as follows: (i) NEWS is a dummy variables which equals one if a transaction is succeeded by an ad-hoc news disclosure in the 20 trading days subsequent to the day of insider trading and zero otherwise. (ii) SUPERVISORY BOARD takes on the value of one if the insider is a member of the supervisory board and zero otherwise. (iii) OTHER INSIDERS, which takes on the value of one if the insider is a member of the group of other insiders and zero otherwise. (iv) TRADING_INTENSITY is defined as the trading volume of the respective transaction divided by the market value of the firm on the trading day. (v) REPORTING_DELAY counts the number of days between the trading day and the reporting day. (vi) MOMENTUM measures the cumulative abnormal return prior to the trading day CAR[-20;-1]. (vii) MULTIPLE TRADERS is a dummy variable which equals one if more than one insider traded the stock on the same day and zero otherwise. (viii) LEGISLATTON equals one if the transaction takes place after the reform of insider trading regulations on October 30, 2004, and zero otherwise. (ix) SIZE equals the natural logarithm of the market capitalization of a firm at the beginning of the respective calendar year. $(x)$ PENNY_STOCK equals one if the respective stock is traded at a price below one euro at the day of the transaction and zero otherwise. (xi) PRICE_TO_BOOK equals the market value compared to the book value of a firm at the beginning of the respective calendar year. (xii) FREEFLOAT quantifies the fraction of shares in the free float. (xiii) BLOCKHOLDER equals one if the respective company has a majority shareholder and zero otherwise. (xiv) SUPERVISORY_BOARD_SIZE and EXECUTTVE_BOARD_SIZE quantify the number of board members in each board. ${ }^{* * *}, * * * *$ indicate statistical significance at the $1 \%-, 5 \%-, 10 \%$-level (two - tailed test). The problem of heteroscedasticity (revealed via the White heteroscedasticity test) is solved by employing robust standard errors (White heteroscedasticity - consistent standard error's). 
As displayed in Panel A of Table 6, the coefficient on the interaction term is significant for this short period $[0 ;+10]$ implying that other insider earn more with front-running transactions compared to members of the executive board. Again, the sum of the coefficient on NEWS and the interaction term NEWS*OTHER INSIDERS measures the profit compared to no news transactions. For the short period, this number shows to be significant on the $5 \%$ - level, while the effect is not statistically significant for the longer event window.

Regarding sales transactions, multivariate regression results confirm the finding that no specific group of insiders seems to be severely engaged in exploiting inside information. In particular, multivariate regression results on the sell side show that profits of insiders are not positively affected by a potential exploitation of inside information.

\section{Concluding Remarks}

Our study analyzes a large sample of corporate insider transactions reported to the German supervisory authority BaFin in the period July 1, 2002 to April 30, 2005 using event study methodology. In particular, we focus on the question whether corporate insiders seem to exploit inside information while trading in company's stock. Our findings reveal that corporate insiders are able to identify profitable investment situations in their firms. E.g., they earn a mean profit of more than four percent in the 20 trading days after they purchase company's stock. We thereby confirm findings of previous studies that insiders' profits for the German market are higher than for the corresponding markets in the US or UK. Furthermore, we find evidence that corporate insiders seem to be engaged in the exploitation of inside information as they earn above average profits by front-running on corporate news. Finally, looking at the type of insider, we find that members of the supervisory board (directors) and the group of other insiders (basically family members of senior managers and directors) are the ones which profit largely by front-running on corporate news. In contrast, members of the executive board (senior managers) do not seem to exploit inside information according to our criterion as they do not realize superior returns with their rare front-running transactions.

However, executive managers cannot be entirely exculpated by our study. One has to keep in mind that executive managers decide upon which impor- tant corporate news qualify as ad-hoc news and thus have to be revealed to the market. In addition, they might also be able to have some influence concerning the timing of the release. This potential discretionary power can, however, only be exercised for unscheduled ad-hoc news like merger announcements or a changes in the executive board. For scheduled ad-hoc news like (quarterly) earnings announcements, executive management lacks discretionary power to time or suppress an ad-hoc disclosure. Consequently, our finding that executive insiders trade less frequently prior to ad-hoc news announcements and that they do not earn exceptional profits with their front-running transactions might be connected to their potential discretionary power concerning ad-hoc releases for unscheduled ad-hoc news. ${ }^{22}$ If one believes in the discretionary power to cheat on unscheduled ad-hoc news releases, one would find some evidence for this interpretation in our data. In particular, executive managers earn a profit of $4.80 \%$ on the buy side with those transactions not succeeded by an ad-hoc news release. Compared to the respective numbers for directors (1.81\%) and other insiders (2.12\%), managers yield high profits. Thus, these high profits might be triggered by an omitted or at least delayed release of inside information via an ad-hoc announcement. However, it could also be triggered by intense mimicking trades of outside investors, who assume members of the executive board to have more valuable information than the two remaining groups of corporate insiders.

Admittedly, our database might not be the ideal sample to study illegal insider trading. This is because intentional and offensive trading on inside information might not be reported to the supervisory authority. In fact, corporate insiders are often suspected not to trade on their own account but giving hints to close friends which trade on their behalf. Given this consideration, we find it interesting that insiders earn high profits with those transactions which they consider to be unproblematic and thus report. Our results suggest watching trading records of corporate insiders closely; especially those trades which are shortly succeeded by an adhoc news announcement. According to our findings, those insiders (e.g., the group of other insiders) who

\footnotetext{
22 The proportion of scheduled (earnings announcements) and unscheduled ad-hoc news (remaining announcements) is rather balanced. For purchases 151 announcements are scheduled while $\mathbf{1 5 6}$ are unscheduled.
} 
are not in the spotlight of the public or the financial press do not seem to fear the scrutiny of the regulator as they earn high profits trading shortly prior to ad-hoc disclosures. Therefore, the BaFin might think about intensifying its monitoring activities as well as its ability to impose sanctions to ensure market transparency and integrity of the German capital market. Nevertheless, we also see the ball in the court of the firms themselves. They have to protect their insiders from allegations, justified or unjustified, by establishing voluntary commitments like blackout periods or trading bans prior to specific corporate events.

\section{References}

Berkowitz, Stephen A. and Dennis E. Logue (2001): Transaction Costs, Journal of Portfolio Management, 27 (2): 65-74.

Bettis, Carr, Don Vickrey, and Donn W. Vickrey (1997): Mimickers of Corporate Insiders Who Make Large-Volume Trades, Financial Analysts Journal, 53 (5): 57-66.

Betzer, André, and Erik Theissen (2005): Insider Trading and Corporate Governance - The Case of Germany, forthcoming European Financial Management.

Betzer, André, and Erik Theissen (2007): Delays in Trade Reporting By Corporate Insiders, Working Paper, University of Bonn.

Bhattacharya, Utpal and Hazem Daouk (2002): The World Price of Insider Trading, Journal of Finance, 57 (1): 75-108.

Boehmer, Ekkehart, Jim Musumeci, and Annette B. Poulsen (1991): Event-Study Methodology under Conditions of EventInduced Variance, Journal of Financial Economics, 30 (2): 253272.

Brown, Stephen J. and Jerold B. Warner (1985): Using Daily Stock Returns - The Case of Event Studies, Journal of Financial Economics, 14 (1): 3-31.

Corrado, Charles J. (1989): A Nonparametric Test for Abnormal Security-Price Performance in Event Studies, Journal of Financial Economics, 23 (2): 385-395.

Eckbo, B. Espen and David C. Smith (1998): The Conditional Performance of Insider Trades, Journal of Finance, 53 (2): 467498.

Elliott, John, Dale Morse, and Gordon Richardson (1984): The Association between Insider Trading and Information Announcements, Rand Journal of Economics, 15 (4): 521-536.

Fama, Eugene F. and Kenneth French (1993): Common Risk Factors in Returns on Stocks and Bonds, Journal of Financial Economics, 33 (1): 3-56.

Fama, Eugene F. and Kenneth French (1995): Size and Book-toMarket Factors in Earnings and Returns, Journal of Finance, 50 (1): 131-155.

Fidrmuc, Jana, Marc Goergen, and Luc Renneboog (2006): Insider Trading, News Releases and Ownership Concentration, Journal of Finance, 61 (6): 341-372.

Finnerty, Joseph E. (1976): Insiders and Market Efficiency, Journal of Finance, 31 (4): 1141-1148.
Friederich, Sylvain, Alan Gregory, John Matatko, and Ian Tonks (2002): Short-run Returns around the Trades of Corporate Insiders on the London Stock Exchange, European Financial Management, 8 (1): 7-30.

Givoly, Dan and Dan Palmon (1985): Insider Trading and the Exploitation of Inside Information: Some Empirical Evidence, Journal of Business, 58 (1): 69-88.

Gregory, Alan, John Matatko, Ian Tonks, and Richard Purkis (1994): UK Directors' Dealings: The Impact of Dealings in Smaller Firms, Economic Journal, 104 (422): 37-53.

Hillier, David and Andrew P. Marshall (2002): The Market Evaluation of Information in Directors' Trades, Journal of Business Finance and Accounting, 29 (1-2): 77-110.

Jaffe, Jeffrey F. (1974): Special Information and Insider Trading, Journal of Business, 47 (3): 410-428.

Jeng, Leslie A., Andrea Metrick, and Richard Zeckhauser (2003): Estimating the Return to Insider Trading: A PerformanceEvaluation Perspective, Review of Economics and Statistics, 85 (2): 453-471.

John, Kose and Larry H. P. Lang (1991): Insider Trading around Dividend Announcements: Theory and Evidence, Journal of Finance, 46 (4): 1361-1389.

Karpoff, Jonathan M. and Daniel Lee (1991): Insider Trading Before New Issue Announcements, Financial Management, 20 (1): 18-26.

Ke, Bin, Steven Huddart, and Kathy Petroni (2003): What Insiders Know about Future Earnings and IIow They Use It: Evidence from insider trades, Joumal of Accounting and Economics, 35 (3): 315-346.

Keim, Donald, B. and Ananth Madhavan (1998): The Cost of Institutional Equity Trades, Financial Analysts Journal, 54 (4): $50-69$.

Klinge, Marco, Udo Seifert, and Richard Stehle (2005): Abnormal Returns in the Vicinity of Insider Transactions: Unbiased Estimates for Germany, Working Paper, Humboldt University of Berlin.

Korczak, Adriana, Piotr Korczak, and Meziane Lasfer (2007): To Trade or Not to Trade: The Strategic Trading of Insiders around News Announcements, Working Paper, Manchester Business School.

Kothari, S. P. and Jerold B. Warner (2007): Econometrics of Event Studies, in: Espen Eckbo (ed.): Illandbook in Corporate Finance, Empirical Corporate Finance, Elsevier, Amsterdam et al., 3-36.

Lakonishok, Josef and Inmoo Lee (2001): Are Insider Trades Informative?, Review of Financial Studies, 14 (1): 79-111.

Lee, D. Scott, Wayne H. Mikkelson, and M. Megan Partch (1992): Managers' Trading Around Stock Repurchases, Journal of Finance, 47 (5): 1947-1963.

Leland, Hayne E. (1992): Insider Trading: Should it be Prohibited?, Journal of Political Economy, 100 (4), 859-887.

Lorie, James H. and Victor Niederhoffer (1968): Predictive and Statistical Properties of Insider Trading, Journal of Law and Economics, 11 (1): 35-53.

MacKinlay, A. Craig (1997): Event Studies in Economics and Finance, Journal of Economic Literature, 35 (1): 13-39.

Manove, Michael (1989): The Harm from Insider Trading and Informed Speculation, Quarterly Journal of Economics, 104 (4), $823-845$.

Märzheuser, Michael und Jochen Gutzy (2004): Ad-hoc-Dienstleister in Deutschland, Studien, Heft 1. 
Noe, Christopher F. (1999): Voluntary Disclosures and Insider Transactions, Journal of Accounting and Economics, 27 (3): 305-326.

Rozeff, Michael S. and Mir A. Zaman (1988): Market Efficiency and Insider Trading: New Evidence, Journal of Business, 61 (1): 25-44.

Seyhun, H. Nejat (1986): Insiders' Profits, Costs of Trading, and Market Efficiency, Journal of Financial Economics, 16 (2): 189212.

Seyhun, H. Nejat (1990): Do Bidder Managers Knowingly Pay Too Much for Target Firms? Journal of Business, 63 (4): 439464.

Seyhun, H. Nejat (1992): The Effectiveness of the InsiderTrading Sanctions, Journal of Law and Economics, 35 (1): 149182.

Seyhun, H. Nejat and Michael Bradley (1997): Corporate Bankruptcy and Insider Trading, Journal of Business, 70 (2): 189-216.

Stotz, Olaf (2006): Germany's New Insider Law: The Empirical Evidence after the First Year, German Economic Review, 7 (4): 449-462.

\section{Biographies}

Björn M. Dymke is research and teaching assistant at the chair of Banking at the Eberhard-Karls-Universität Tübingen. His research interests include insider trading, investment theory and valuation. Recently, he received the best paper award (WaltherRathenau-Preis) at the $8^{\text {th }}$ Symposium of the German Economic Association of Business Administration (GEABA).

Andreas Walter is associate professor at the chair of Banking at the Eberhard-Karls-Universität Tübingen. He holds a master's degree in business administration (2000) and a doctoral degree (2002) from this institution. His research interests include empirical corporate finance, investor behavior and corporate governance. Recently, he received the SWX best paper award at $11^{\text {th }}$ Conference of the Swiss Society for Financial Market Research and the Walter-Rathenau-Preis at the $8^{\text {th }}$ Symposium of the German Economic Association of Business Administration (GEABA) In 2007 he also received the excellence award for young researchers from the Eberhard-Karls-Universität Tübingen sponsored by the Commerzbank Foundation. 